\title{
Editorial
}

\section{The Question of (Mis)interpreting the Qur'ān by Muslims}

Although the Qur'ān calls Muslims to make peace with their enemies (Qur'ān 8:61-62), some early Qur'ān exegetes ${ }^{1}$ interpret that to be abrogated by subsequent war verses (Qur'ān 9:5; Qur'ān 9:12-13). This, according to a sound methodology, is a misinterpretation. So why is the Qur'ān often taken out of context on many issues, and on peace and war injunctions in particular? In other words, why does misunderstanding seem so pervasive among Muslims of different generations on different matters? This is certainly one of the most important questions in the context of intellectual discussion about the Qur'ān and Islam for at least two reasons:

1. The consequences of this question effectively undermine all genuine efforts to both divorce Qur'ān or Islam from the misconducts of some Muslims on several fronts, and to convey its universally positive messages.

2. The implications of this question appear to lend some credence to the claims and analyses of those who see the pervasive nature of this misunderstanding as truly representing Islam - one that, in their eyes, has to be considered rather genuine. Here, their underlying presumption is that there is no "misunderstanding" of the Qur'ān, for the very fact of its pervasiveness means that it must be the true representation.

The following are some honest attempts to offer a much-needed explanation in the face of these two potent and critical observations, but not as a way to justify the problem. Although the pervasive nature of misunderstanding the Qur'ān may be overplayed (one always finds dissenting voices that tend to offer more logical and supported opinions - in this case, al-Ṭabarī or Ibn al-'Arabī, the Jurist), it is true that Muslims rarely acknowledge it as a problem, hardly address it adequately, or even contemplate its negative implications for Islam. The misguided understanding of the verses of peace and war, for example, came about through a delicate interplay of at least three factors - namely, interpretive methodology, cultural environment, and ideological pursuits - each of which is analyzed below. 


\section{Interpretive Methodology}

As a scripture or an important text, the Qur'ān has to be interpreted if it is to be applied correctly. Interpretation inevitably leads to diverse understandings and applications. It can safely be stated that, from a modern perspective, the early Muslims lacked adequate methods of interpretation even though, according to some experts, the first generations hardly needed one. ${ }^{2}$ While it is correct that some later interpretations were done on an ad hoc basis, such classical Qur'ān commentators as al-Ṭabarī (d. 923), al-Zamakhsharī (d. 1144), and Fakhr al-Dīn al-Rāzī (d. 1210) presented elaborate methodologies in the introductions to their commentaries. Ignaz Goldziher (d. 1921), in his Madhāhib al-Tafsìr al-Islāmī (originally in German), did a fine job of analyzing the approaches and contents of classical Qur'ān commentaries. ${ }^{3}$ In addition to these commentaries where one can glean something of their methodologies, Ibn Taymiyyah's (d. 1328) Muqaddima fi Ușul ' $l$-Tafsìr ${ }^{4}$ is specifically geared toward the principles of Qur'ānic exegesis, for in his book, he delineates the appropriate ways to understand and interpret the Qur'ān. Modern Qur'ān commentaries also have extensive introductions, in which their authors expound upon their methodologies. Perhaps the best works analyzing these sources, including the classical ones, are Muhammad Husayn al-Dhahabī's (d. 1977) Al-Tafsìr wa 'l-Mufassirūn and Helmut Gatje's (d. 1986) The Qur'ān and its Exegesis (trans.).

Even though early Muslim exegetes brought different orientations (theological, legal, philological, philosophical, historical, mystical) to their exegetical exercises, they had common approaches. The orthodox insisted that the best method (manhaj) to use in interpreting the Qur'ān must include: a proper investigation of the Qur'ānic words (thus, utilizing all aspects of Arabic sciences); a consideration of the content of the Sunnah as a tool; and the use of the Qur'ān itself (as parts of it explain other parts) as a reference. This method is admittedly a sound one. But as it is insufficient in some ways, its application has been sporadic, failing in many cases to yield any consistent conclusions.

Regardless of any orientation cited above, the most transparent and easily applicable method I use and urge scholars to adopt is a modified version of the "hermeneutical model," in which three main components should be considered. They are: "the grammatical composition of the text's" actual words; "the context in which the text was written"; and taking the contents "of the whole text" and its overall worldview into account. ${ }^{5}$ The first component of this model is almost identical to that followed by early Muslim exegetes. Yaḥyā ibn Ziyād al-Farrā' (d. 822/3), Ibrāhīm ibn al- 
Sārī al-Zajjāj (d. 923), Maḥmūd al-Zamakhsharī (d. 1144), and many other earlier Muslim linguists, philologists, and grammarians, have applied this method almost flawlessly. ${ }^{6}$ But this method allows experts to discern the closest meaning of the Qur'ān only if it is coupled with proper and consistent application of the model's other components.

As the second component of the hermeneutical model (the context) is also acknowledged by Muslims scholars and utilized in ușūl al-fiqh for instance, ${ }^{7}$ its application in Qur'ānic commentary has been notoriously selective and sporadic. However, some classical scholars insisted on what may come close to being equivalent to the third component: tafsir 'l-Qur'ān bi 'l-Qur'ān (interpreting the Qur'ān by the Qur'ān). Unfortunately, this method's application was restricted to verses about similar issues that are found in other chapters. But what this component requires must go beyond the simple and direct intra-Qur'ānic references of similar verses to include, more urgently, the verses that speak of other important values and the worldview of Islam. In other words, scholars should go beyond the popular dictum that "parts of the Qur'ān interpret other parts" (al-Qur'ān yufassiru ba 'duhū ba 'dā), according to which they highlight similar themes and stories in other parts of the Qur'ān. In fact, scholars should actually be cognizant of other important themes - which may not be directly related to the specific subject under discussion, but are, nevertheless, crucial to the cohesiveness of the Qur'ān's message and Islam's worldview. For instance, when interpreting the verses of peace one must be careful not to jeopardize the other verses on values that Islam holds dear - among them justice, honesty, respect for humanity, religious pluralism, and trust in God. To completely ignore - or, to say the least, to inadequately apply, such other verses -will likely lead scholars away from the Qur'ān's proper intention and certainly toward the abuse of its message. And yet, many scholars, regrettably, lost sight of this very method. And therein lies the laxity of many scholars and the prime source of misinterpretation of the Qur'ān.

My analysis, to be sure, is informed by modern considerations as well as my exposure to the hermeneutical model. Therefore, premodern Muslim scholars would have generally approached the Qur'ān either with imperfect methodologies (though perfect for their generations) or without strictly following their own expressed methodologies of interpretation. Modern traditional scholars have followed suit with no change in attitude, but with a rather alarming sense of loyalty to the contents and approaches of the classical sources. 


\section{Cultural Environment}

Lack of adequate methodology as a problem of interpreting, for example, peace and war verses is compounded by the prevailing atmosphere of war in the premodern world. According to Fred Donner in "The Sources of Islamic Conceptions of War," the Muslims' understanding and construction of war was a result of what was prevailing in their region. He contends that it may not even be adequate to rely only on the Qur'ān and the Sunnah to fully understand their concept of war. In other words, war was part of the world's culture, including that of the ancient civilizations. ${ }^{8}$ That the cultural environment of medieval Muslims always anticipated wars makes the misunderstanding of Qur'ānic injunctions of peace and wars quite easy - and, to the amazement of modern observers, not terribly unbelievable, even if utterly unacceptable to me.

Such a statement is true because no matter how the new revelation (the Qur'ān) intended to change the status quo and tried to regulate war-like attitudes and expectations, some of the cultural dictates - such as the feeling of retaliation, the imposing peace with ransom, and the calling for peace only when one is on the losing side - will eventually prevail, either totally or partially. And scholars are likely to promulgate such attitudes in their commentaries, for they are not immune from such cultural realities. Hence their opinions, no matter how sincere, will sometimes reflect the effects of their cultural environment. This, coupled with possible misinterpretation, opens more avenues for misrepresenting the Qur'ān. The consequences of this factor assumes a sad and dangerous significance when subsequent generations of Muslims, including modern-day extremists - while heedless of the implications of contextuality - accept the earlier interpretations as perfect, final, and binding as they continue to invoke them. It is also regrettable when critics consider these interpretations as the true and only representatives of Islam.

Now, is the cultural environment of the contemporary world any different? In other words, is the modern world, as opposed to the ancient world, focused on peace? Based on the ongoing wars, it may be hard to believe that the default state of modern world is actually peace, not war. Sherman Jackson argues that, currently, peace is the rule and war the exception. In the twentieth century, at least, following the First World War and certainly after the Second World War, the world community deliberately declared peace to be the norm. Therefore it must be considered as such, even with the impending wars. ${ }^{9}$ The fact that the most powerful nations have to justify their engagement in wars to the international community, despite evidence of occasional manipulation and "politicking," is a strong attestation to the changed reality of the world in favor of peace. 
This is a compelling case for contemporary Muslims to seek peace,. for they live in a cultural environment that differs markedly from that of their medieval counterparts. So, they have to accept the peace verses as continuously binding and the reality that, while they cannot depend on medieval concepts of war anymore, the world will not allow them to engage in unilateral declarations of wars either. Add to this the fact that the majority of Muslim nations have inferior armies and lack the most sophisticated weaponry. In the end, the impact of cultural environment on Muslims' understanding regarding issues of war and peace is similar to that of their interpretation of roles and issues of women and other important matters.

\section{Ideological Pursuits}

Another crucial factor that leads many Muslims to read the Qur'ān in ways that ignore its intended purposes is ideological pursuits. The common and effective way of doing this is to impose on its verses any understanding that supports their positions - an understanding that can also change as circumstances dictate. This practice, on the one hand, is motivated by the authority that, they believe, has been vested in the Qur'ān and, and on the other, by the Muslims' practice of trying to justify all their actions through the contents of the Qur'ān.

Even in the beginning years of Islamic political and theological debates, the medieval scholars used certain verses in their arguments that would have been rejected had their interpretations been subjected to any meaningful methodological approach. One only needs to study the later debates between theologians (the members of the $\mathrm{Mu}^{\text {'tazilah and the }}$ Ash'ariyyah schools) to find out how sporadic they used verses (despite the evidence of reasoning in their arguments). To them, in an unconscious way, the goal of ideological pursuit not only justifies, but actually facilitates, their understanding of all verses, and thus, their unique interpretations. Ironically, a typical example of such usages comes from the debate over the createdness of the Qur'ān itself. Representing the Mu'tazilah, the Abbasid caliph al-Ma'mūn 'Abd Allāh ibn Hārūn (r. 813-833) vigorously argued in favor of the createdness of the Qur'ān, citing Qur'ān (43:3): "We have made it a Qur'ān in Arabic." The Mu'tazilah argue that by using "made" (ja 'alnā), the Qur'ān is treated as other creatures; and that it came into existence after it was nonexistent. For this, they insist that it must be created - apparently, a simple logical conclusion, made only to support their position, but hardly the intention of the verse. Other verses they used for their theological belief in the createdness of the Qur'ān, which may be construed as an imposition include: Qur'ān (16:40); Qur'ān (20:99); 
Qur'ān (21:50); Qur'ān (38:1); and Qur'ān (85:21-22). ${ }^{10}$ These examples are meant to highlight the Mu'tazilah's sporadic - albeit, sometimes logical use of the Qur'ân - and not to attack them.

This tendency, even though used easily among medieval Muslims for different purposes, remains unchallenged in the modern era. To many Muslims, the objective is to somehow acquire the Qur'ān's support and then apply it, pure and simple. They do not need to give a great deal of thought to its "proper understanding," even though applying it "improperly" may be more fatal and counterproductive. In conjunction with peace for example, a medieval Muslim scholar - supported by his cultural norms, unfazed by any dictates as universal as today's various international conventions on peace and human dignity, and not guided by any viable methodology - may be unabashedly, even if wrongly, interpreting the peace verse as temporary in nature or as simply incorrect. Given their different sets of circumstances, contemporary Muslim scholars cannot convincingly justify the same approach and conclusions for themselves. Yet, most of them do it effortlessly and unconsciously with a sense of pride.

Interestingly, this tendency has little to do with a lack of knowledge, for immensely knowledgeable scholars may fall victim to it. Early scholars like al-Hasan al-Bașrī, who may hold the ideology that all of Arabia's inhabitants must become not only Muslim but also pious ones, will be more likely to see nothing wrong with abrogating the peace verse. This reality speaks volumes about Islam's predicament, especially when coupled with religious and sociopolitical fanaticism. It is even more dangerous in modern times, when all sorts of ideologies (especially political) have to justify their relevance through the Qur'ān and prove their authority under intense sociopolitical competition.

The persistence of ideological pursuits, the impact of cultural environment, and the paucity of effective methodologies make the Qur'ān's call to peace hopelessly pessimistic and the achievement of an enduring peace quite elusive. These situations, although compounded by the potential aggression of other nations, will hopefully get better for Muslims only when, in a broader scheme, methodology finally trumps ideology. ${ }^{11}$

\section{This Issue}

We open the 2012 second issue of AJISS with the "Foundations of Islamic Antidrug Abuse Education" by Syed Zahir Idid and Abdurezak A. Hashi. While they explore the rationale and jurisprudential foundations of Islamic antidrug abuse education, they highlight the philosophical background of the Islamic antidrug teachings and the jurisprudential foundations of the legal penalties for drug abusers. Using the Qur'ānic terms and the Prophetic 
statements, Idid and Hashi also analyze the opinions of Muslim jurists and theologians.

The next article is "Accessing Global Information: The Use of the Internet for Current Islamic and Non-Islamic Issues by Students in Solo, Indonesia,” written by Benina Gould, Yayah Khisbiyah, and Jeffrey B. Gould. The authors surveyed sixty-one students - ages fifteen to nineteen from three pesantrens, three madrasahs, and one secular high school in Solo, Indonesia - and asked them to recommend three Internet sites and the reasons for their choice. They found that regardless of student outlook the Internet was not a major source of Islamic or non-Islamic news.

Khosrow Bagheri Noaparast and Mohammad Zoheir Bagheri Noaparast follow with their "Action-Oriented Research in Education: A Comparative Study on A Western and An Islamic View." Noaparast and Noaparast focus on action-oriented educational research based on Charles Clark's view, which they compare to one inspired by the Islamic view on human action. They conclude that there are considerable commonalities and differences between the two views.

The final article in the research paper section is "Muslim Representations in Two Post-September 2001 American Novels: A Contrapuntal Reading of Terrorist by John Updike and Falling Man: A Novel by Don DeLillo" by Seyed Mohammad Marandi and Zeinab Ghasemi Tari. They observe that although these novels have been written in the twenty-first century, where there has been an increase in contacts with and information about Muslims, the writers often use the same cliches and stereotypes about Muslims that have existed since the Middle Ages.

In the forum section, we begin with Khaleel Mohammed's "Between Creed and Qur'ān: Shi' ite Views of 'Ișmah in Light of Qur'ān (48:1-2)" on the concept of prophetic "infallibility" as presented by the popular Shī'ah exegetes of the Qur'ān. Next is Mazen Hashem's “The Levant Reconciling a Century of Contradictions" where he presents some perspectives about Syria.

Finally, I hope that together, these excellent papers will not only present our readers with thought-provoking discussions, but inspire in them the intellectual passion to actively participate in the ongoing debates on an array of issues.

\section{Notes}

1. Such as Qatādah ibn Di‘āmah (d. 735) and al-Ḥasan al-Bașrī (d. 728). 
2. For more details, see Muḥammad Husayn al-Dhahab̄i, Al-Tafsīr wa 'l-Mufassirūn, 3 vols. (Cairo, Egypt: Maktabat Wahbah, 1995).

3. See Ignaz Goldziher, Madhāhib 'l-Tafsīr 'l-Islāmī, trans. 'Abd AlHalīm al-Najjār (Cairo, Egypt: Maktabat 'l-Khanji, 1955) and alDhahabī, Al-Tafsīr, 3 vols.

4. Aḥmad Ibn 'Abd al-Halīm ibn Taymiyyah, Muqaddimah fì Ușūl $a$-Tafsīr (Beirut. Lebanon: Maktabat al-'Asriyya, 2009).

5. Amina Wadud, Qur' an and Woman: Rereading the Sacred Text from a Woman's Perspective (New York and Oxford: Oxford University Press, 1999), 3.

6. For more, see Yahyyā ibn Ziyād al-Farrā', Ma 'ān̄̄ 'l-Qur'ān (Beirut, Lebanon: Dār al-Surūr, 1988); Ibāhīm ibn al-Sārī al-Zajjāj, Ma 'ān̄̄ 'l-Qur'ān wa I'rābuh, 5 vols. (Beirut, Lebanon: 'Ālam al-Kutub, 1988); and Mạ̣mād ibn 'Umar al-Zamakhsharī, Al-Kashshāf 'an Haqū'iq al-Tanzīl wa 'Uyūn 'l-Aqāwīl fì Wujūh 'l-Ta'wīl, 4 vols. (Beirut, Lebanon: Dār al-Ma 'rifah, 1990).

7. For more detail, see, 'Alī ibn Aḥmad Ibn Hazm, Al-Iḥkām fì Ușūl 'l-Ahkām, 8 vols. (Beirut, Lebanon: Dār 'l-Kutub 'l- 'Ilmiyyah, 2004) and Ibrāhām ibn Mūsāal-Shāṭib̄i, Al-Muwāfaqāt fì Uṣūl 'l-Shari 'ah (Beirut, Lebanon: Dar 'l-Kutub al-'Ilmiyyah, 2004).

8. Fred Donner, "The Sources of Islamic Conceptions of War," in Just War and Jihad: Historical and Theoretical Perspectives on War and Peace in Western and Islamic Traditions, ed. J. Kelsey and J. T. Johnson (New York: Greenwood Press, 1991), 34.

9. Sherman Jackson, "Jihad and the Modern World," in Islam in Transition: Muslim Perspectives, ed. John J. Donohue and John L. Esposito (New York and Oxford: Oxford University Press), 402.

10. 'Alī ibn Ismā'īl al-Ash`arī, Maqālāt 'l-Islamiyȳ̄n wa 'khtilāf 'l-Mușallīn (Cairo, Egypt: Maktabat 'l-Nahḍat 'l-Mișriyya, 1954) 232; Montgomery Watt, "Early Discussions about the Qur'an," The Muslim World 40 (1950): 33.

11. It will not be surprising if some readers, instead of considering this editorial's arguments from an intellectual perspective, will dismiss it based on their particular ideological stance.

Zakyi Ibrahim, Ph.D, Editor, AJISS, 